\title{
COUGAR, LYNX AND DEER OBSERVATIONS FROM MANITOBA AND BRITISH COLUMBIA BY H. M. LAING
}

Introduction by ROBERT W. NERO, 546 Coventry Road, Winnipeg, MB R3R 1B6

Richard Mackie's biography of $\mathrm{H}$. M. Laing (1883-1982) provides an abundance of information on the life of this early "hunter-naturalist" and his extensive natural history contributions. ${ }^{3}$ I first became acquainted with Mack Laing through studying the birds of Lake Athabasca. ${ }^{4}$ Laing had been a member of a U.S. Biological Survey party that conducted field work there in 1920.

After my family and I moved to Manitoba in 1966, I perused with interest Laing's early account of birds in the Oak Lake area of the southwestern part of the province. ${ }^{1}$ Later, a further account of Laing's experiences with birds in Manitoba was published by him in Blue Jay. ${ }^{2}$ That article, not mentioned in Mackie's book, was written when Laing was 96; it came about through the encouragement of Stuart Houston, who began corresponding with Laing in 1969. Our work on the Cougar in Manitoba led to further correspondence between Laing and myself. ${ }^{5}$ Recently, I looked over several letters from Laing that I have treasured and I decided that his comments on Cougars deserved to be published.

What follows is excerpted, and slightly modified, from Mack Laing's lengthy handwritten letter of January 1 1974, sent to me from his home at Comox, BC after I had sent him sketches of possible Cougar tracks.

\section{Laing writes:}

And now for the cougar lore. I was very interested in your records of the big cat in Manitoba. We can't forget that he was always there. The Tiger Hills on the southern border of the province were so named back in the days of Henry's journals. In 1904 and '05 that I spent in the Boissevain district [due south of Brandon, MB], I heard nothing of the big cat in Turtle Mountain southward or Souris River northward. But in 1903 at Oak Lake [ just west of Brandon, MB], I met David McLeish whose farm was about a mile south of town and he told me of seeing an animal of the cat kind, bigger than a coyote, tawny of colour, that crossed his farm heading for the sandhills southward. It had come from the wooded Assiniboine valley northward.

The lynx at Oak Lake was periodically a very common winter visitor. In 1907 , Robert Alford, on five consecutive nights, trapped one, missed the sixth night and clicked again on the $7^{\text {th }}$. But Alford never reported any evidence of the cougar, perhaps because in pioneer days (he settled in 1885) there were very few deer in the area in the 1880s, and those present were mule deer.

I saw my first white-tailed deer at Oak Lake in 1908 in July. He jumped up from the brush in the early dusk as I was in the big Flat Creek ravine. When I saw that big long flag waving at me I thought I must be seeing things. But I knew it, for in the two years (1901-02) I taught at Glenora [ $80 \mathrm{~km}$ southeast of Brandon] on the Rock Lake prairies, I got well acquainted with white-tails in the splendid wooded areas of that region - 


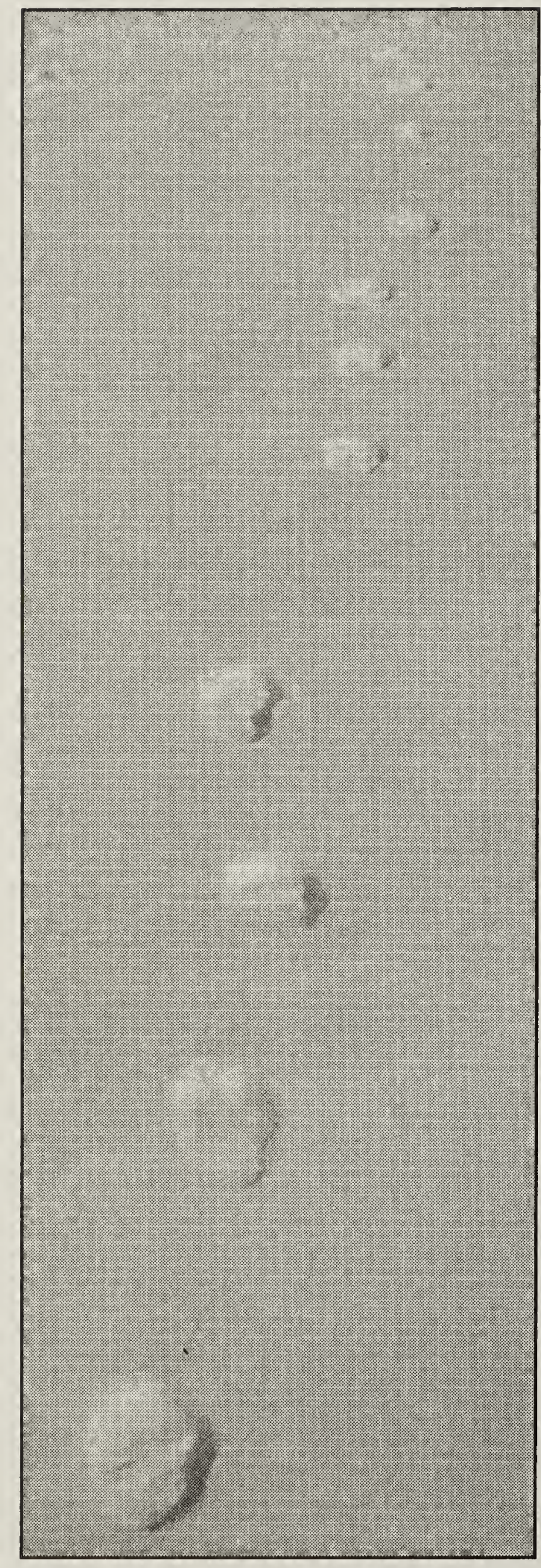

Lynx tracks

Lorne Scott

extensive forests of oak and lots of browsing areas of shrubbery. In 1951 or '52, a former Oak Lake pupil reported that he had recently seen, in winter on one of the farms on the floor of the Assiniboine valley, as many as 80 -odd white-tails in a wintering flock. An abundance of deer like that would mean that the big deer-killing cat was bound to come.

I can't say much about your problem with the tracks from the evidence of your careful diagrams and notes. I am sorry that I did not make photographic studies of both lynx and cougar tracks. I think likely you were following a cougar all right. There is no weight to a lynx. The fact that your cat made prints "fairly deep on a hard-packed road" implies that the beast had some considerable weight. The size of your prints doesn't mean much, though $3 \frac{1}{2}$ in. would be about right for an adult female cougar. The appearance of a lynx is mostly a fraud. His deceptive front legs are slender and weak, the toes long and slender. In snow, he spreads his long toes for a snowshoe and leaves the print of a big animal. The length of his jumps while running would vary. On the other hand, the cougar is short-furred and shows his solid build. Big old males run to $150 \mathrm{lbs}$ and even over.

When I first came to Comox [on the eastern shore of Vancouver Island] in 1922, a cougar's track in the neighbourhood was common enough. In 1923, I built my first home at the mouth of Brooklyn Creek. I was surrounded by 30 acres of timber on three sides. One night I came home near midnight carrying my 'bug' (can and a candle) on a dubious trail along the beach. When I was about to step off the home end of my creek footbridge plank, I noted 2 of the finest, freshest cougar prints you ever saw melted into the frost on the plank. The cat had noted the new house on his beat and stood on the bridge at midnight to think it over. I thought things over too. 
Although the cougar is difficult to see, he can be very brash. One evening in the 1930s, my wife and I were reading at the fireplace, the two springers warming their heads at our feet. I got up to get a new slab of firbark from the woodbox on the veranda. In the light from the door I saw tracks in the frost on the steps, cougar! - a big fellow too - the prints spread widely. He had come up about 6 steps to the floor of the veranda on which there was no frost. He didn't leave by the stairs but jumped over the south railing, ten feet from the ground. Not even the dogs heard a sound. Undoubtedly he went to the woodbox and looked in the window. Maybe the sight of the fire deterred him. But I think I worked it out correctly after a look-see from the lawn. From about 25 yards away, the heads of three mounted bucks: black-tail, white-tail and mule deer, stood out like three splendid bucks looking out through the fireplace wall. What a sight.

I got a lot of my cougar lore from my neighbor, good friend and hunting pal
John Cecil "Cougar" Smith who spent most of his life hunting the big cats for bounties. Vancouver Island, I expect, had the heaviest cougar population in America.

Don't hold your breath expecting to see a cougar track with the tail dragging in the snow. They just don't do it. He has great respect for his fine appendage, but I don't know what service it serves his life history. Probably it is a stabilizer and rudder to his flying leaps.

In my 52 years at Comox, only twice have I seen a cougar in the natural, not treed by dogs. Once, when backpacking up the old Holberg trail to Cape Scott, as I rounded a curve I spied the rear of a big animal as it was disappearing in the woods. It was tall and tawny with a black spot, and I said "Ho hum, another blacktail" when, in a flash of intelligence, I realized that no black-tail carried his marker so low and there was no sign of white fringe. I had seen a very big cougar.

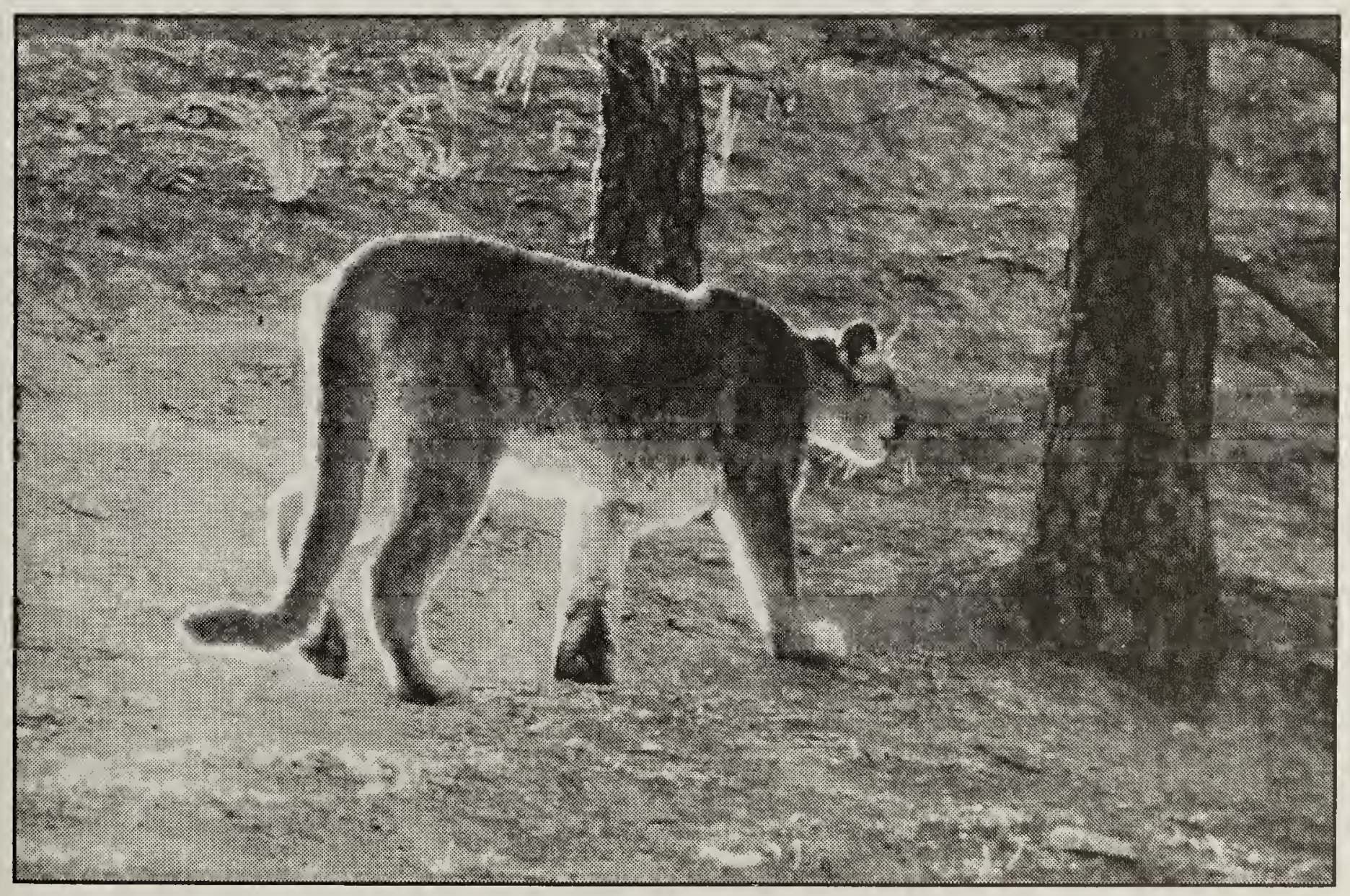

\section{Cougar}


On my other chance meeting, I was at Upper Campbell Lake, also in summer. I was sitting on a log at right angles to the road in the timber listening for the squeal of black pigeon hawks [Merlins]. Hearing nothing for a while, I stood up and turned to face the road and found myself face to face with a female cougar. She had come on me behind my back. She did an about turn nimbly enough, but not scared at all and went back up the road in that ambling gait that in the open appears awkward - nothing smooth, direct and catlike about it. It reminded me of a western Mule Deer making a break away in the open where there is no brush to bounce over as in Manitoba, and the clown doesn't know whether to trot, walk or pace! - H. M. Laing
1. Laing, H. M. 1913. Out with the Birds. Outing Publ. Co., New York. 249 pp.

2. Laing, H. M. 1980. Early Manitoba bird notes. Blue Jay 38: 96-114.

3. Mackie, R. 1985. Hamilton Mack Laing: Hunter-naturalist. Sono Nis Press, Victoria, B.C. 234 pp.

4. Nero, R. W. 1963. Birds of the Lake Athabasca Region, Saskatchewan. Saskatchewan Natural History Society, Special Publication No. 5, Regina. 143 pp.

5. Nero, R. W. and R. E. Wrigley. 1977. Status and habits of the Cougar in Manitoba. Canadian Field-Naturalist 91 : 28-40.

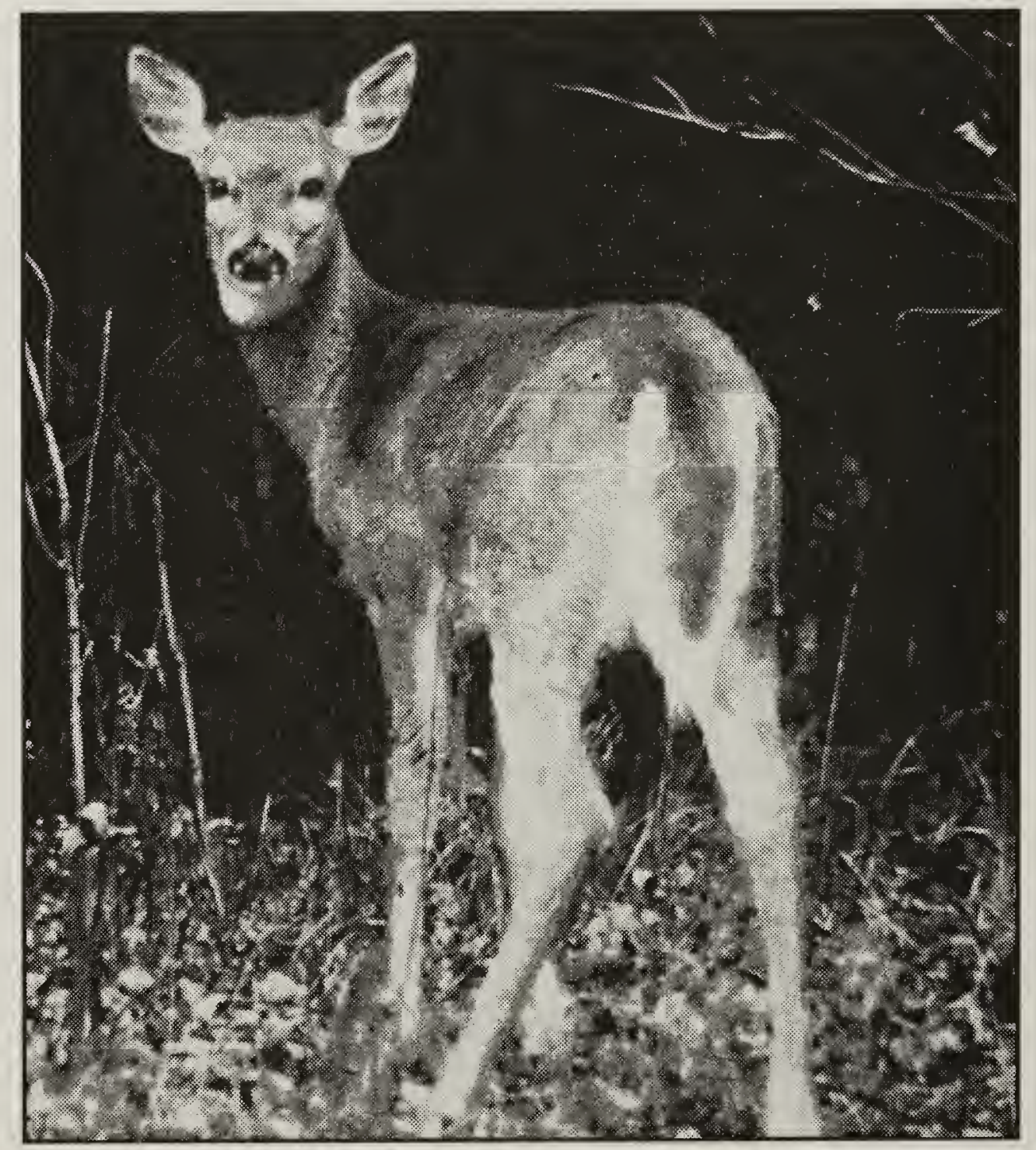

